\title{
EFFECT OF PROTEIN LEVELS ON GROWTH PERFORMANCE AND ECONOMICAL EVALUATION OF NILE TILAPIA (Oreochromis niloricus)
}

\author{
Abd El-Hamid Eid ${ }^{1}$; Mostafa, M. Saiid ${ }^{2}$ and Abdel-Rahman, A. \\ Salama ${ }^{3}$ \\ 1- Department. of Animal \& Fish Production, Fac. Of Agric. Suer. \\ Canal Univ. - Ismailia - Egypt. \\ 2- Department of Aquacuiture, Desert Research Center, Egypt. \\ 3- Department of fish Economics, Central Laboratory for Aquaculture \\ at Abbassa, Sharkia Governorate, Egypt.
}

Key words: Proiein levels, Nile tilapia, growth performance, productivity, economic efficiency.

\section{ABSTRACT}

Qix approximately isoenergetic diets were formulated with protein Olevels from $20 \%$ to $45 \%$ in increments of $5 \%$. The effects of varying dietary protein level on growth performance and economic efficiency were studied. The best growth rate was obtained with $30 \%$ dietary protein, followed by the diets containing $35,40,45,25$ and $20 \%$ protein, respectively. Feed conversion ratio was improved with increasing dietary protein levels up to $30 \%$. Protein efficiency ratio was decreased with increasing dietary protein levels.

Body protein was increased with increasing dietary protein levels up to $45 \%$. There was an inverse relationship between the body moisture and lipid contents. Dietary protein levels did not affect the body ash content. From the economical point of view, the highest net return percentage of the total costs was $110.3 \%$ as recorded by the $30 \%$ Protein; followed by $102.4 \%$ (25\%. Protein) $99.4 \%$ (20\%. Protein); $94.1 \%$ (35\%. Protein); $59.0 \%$ (40\%. Protein) and finally $48.6 \%$ for $(45 \%$. Protein). The optimum dietary protein level for Nile tilapia (weighing 20g) was $30 \%$ and the feeding rate was $3 \%$ of body weight.

\section{INTRODUCTION}

- In recent years an increased interest in aquaculture has revealed the lack of knowledge concerning nutritional requirements of fish, although they have many of the dietary requirements as warm blooded species. The dietary protein requirements of several species of young 
fish have been reviewed (NRC, 1983 Cowey et al., ivgs, in general, the values ranged from about 30 to $55 \%$ cnde proten for maximum growth. Some studies have attempted to detemin: 6 \%act dietary protein requirements of tilapia to maximize growth i.miney, 1982; Santiago et al., 1982; De Silva and Perera 1985; Warig et al., 1985 and Siddiqui et al., 1988). Others have been directed towards identifying low cost, readily available raw materials as protein sources for tilapia diets (Jackson et al., 1982 and Viola and Arieli, 1983;). In spite of these studies, the picture is still not clear and the dietary protein requirements of Nile tilapia still remain inadequate, so, more studies are required.

The aim of the present study was to determine the effects of varying dietary protein levels on growth performance and economical evaluation of Nile tilapia.

\section{MATERIALS and METHODS}

\section{Culture condition:}

Two hundred and forty fish, weighing 20.10 grams on average were used. The fish were divided into 6 groups, each of 20 fish in duplicates. The experiment was conducted in glass aquaria $(80 \times 50$ $\times 40 \mathrm{~cm}$ ) supplied with de chlorinated tap water. Water temperature was maintained at $25^{\circ} \mathrm{C}$ through the experiment by an electric heater. Fish were acclimatized to experimental condition for two weeks prior to the experiment. The experimental period lasted for 60 days. All fish in each aquarium were weighed every 10 days.

\section{Diet and feeding regime:}

The experiment was undertaken at the Fish Research Center, Suez Canal University. Six isocaloric diets containing 20,25, 30, 35, 40 or $45 \%$ protein were formulated (Table 1). The experimental diets were analyzed for moisture, protein, ether extract, crude fiber and ash by standard methods (AOAC. 1980). The composition and proximate analysis of the diets are given in table1. The parameters chosen for the evaluation of the experimental diets were weight gains, relative growth rate (RGR), protein efficiency ratio (PER), feed conversion ratio (FCR), specific growth rate (SGR) and feed efficiency (FE).

Experimental diets were fed at $3 \%$ feeding rate of body weight per day. The daily amount of food was offered two times at $9.00 \mathrm{a} . \mathrm{m}$ and 3.00 p.m. for six days a week. 
Statistical analysis was carried out, using analysis of variance and Duncan's multiple range tests according to Snedecor and Cochrin (1980).

\section{RESULTS and DISCUSSION}

The growh performance of Nile tilapia fed different protein levels is shown in table 2. Diet 3 which contained 30\% crude protein gave significantly $(\mathrm{P}<0.05$ ) the best weight gain. RGR, SGR then diets 4,5 , 6,2 and 1 having $35,40,4525$ and 20 crude protein respectively. However, no significant differences were found between the weight gain of groups of fish fed diets 4.5 and 6 respectively.

It appears from the results of the present study that the level of dietary protein producing maximum growth of Nile tilapia is $30 \%$, as indicated by the growth parameters data presented in Table 2 . In this connection, De Silva and Perera (1985) found that best growth was achieved when ration contained $28-30 \%$ protein. Siddiqui $\%$ al, (1988) found also that the protein requirement of young Nile tilapia (weighing $40 \mathrm{~g}$ ) was $30 \%$ protein. Wang et al., (1985) reported better growth with $30 \%$ protein diet than diet containing $40 \%$ protein and the maximum growth was obtained with a diet containing $25 \%$ protein fed at the rate of $3.5 \%$ body weight per day.

Based on various studies, Balarin and Haller (1982) summarized the protein requirements of various size groups of tilapia as:

\begin{tabular}{|c|l|c|}
\hline Group & \multicolumn{1}{|c|}{ Weight (g) } & \% protein requirement \\
\hline $\mathbf{1}$ & Up to 1 & $\mathbf{3 5}-\mathbf{5 0}$ \\
$\mathbf{2}$ & $1-5$ & $\mathbf{3 0}-\mathbf{4 0}$ \\
$\mathbf{3}$ & $5-25$ & $\mathbf{2 5 - 3 0}$ \\
$\mathbf{4}$ & 25 and more & $\mathbf{2 0 - 2 5}$ \\
\hline
\end{tabular}

Diets $3,4,2$, and 5 (containing $30,35,25$ and $40 \%$ crude protein) gave significantly better feed conversion ratios (Table 2) than diets 1 and 6 (having 20 and $45 \%$ crude protein). The best-feed conversion ratio was found with $30 \%$ protein diet. Similar results were obtained by Jauncey (1982), De Silva and Perera (1985) and Siddiqui et al., (1988). 
Average protein efficiency ratios (PER) values for the experimental diets are presented in table 2. gentraly 10 recreased with increasing dietary crude protein lerel gradu $y$, been noted in O. mossmbicus (Jauncey, 1982); O.nilo iv Siddiqui et al., (1988) and other fish species (Ogino and Saito, 1970; Dabrowski, 1997 and Jauncey, 1982).

Diets 3 and 4 (having 30 and $35 \%$ crude protein) gave significant $(\mathrm{P}<0.05)$ better-feed efficiency than diets $2,5,1$ and $6(25$, 40,20 and $45 \%$ crude protein) respectively.

The gross body composition presented in Table 3 shows that fish fed the lowest dietary protein level $(20 \%)$ tend to have lower moisture and protein contents, and significantly higher lipid content. There was an inverse relationship between body moisture and lipid contents. Similar results were obtained by other authors (Atack et al., 1979 and Jauncey, 1982). The lowest protein content was that of fish fed low protein diets. Similar results were reported by Jauncey, (1982) and Siddiqui et $a l ., 1988$ ). The ash content was unaffected by different dietary protein levels, as has been reported with other fish species (Dabrowski and Wojno, 1977; Atack et al., 1979; Jauncey. 1982; Sidiqui et al., 1988).

\section{Economic efficiency:}

Table (4), shows the results of economical evaluation including the costs, total fish production $\mathrm{Kg}$. per $/ \mathrm{m}^{3}$ for 180 days and net returns for treatments applied in L.E. Total costs were found to be $79.86 ; 79.61 ; 80.45 ; 83.9 ; 94.69$ and $109.0 \mathrm{~L} . \mathrm{E} / \mathrm{m}$ ' for the T1 $(20 \%$ Protein); $\mathrm{T}_{2}$ (25\% Protein); $\mathrm{T}_{3}$ (30\% Protein); $\mathrm{T}_{4}$ (35\% Protein); $\mathrm{T}_{5}$ (40\% Protein) and $\mathrm{T}_{6}$ (45\% Protein); groups, respectively. These results revealed that the total costs of $T_{3}$ (45\% Protein) were the highest $\left(109 \mathrm{~L} . \mathrm{E} / \mathrm{m}^{3}\right)$ than other groups. On the other hand, the total costs of $\mathrm{T}_{2}\left(25 \%\right.$ Protein) were the lowest $\left(79.61 \mathrm{~L} . \mathrm{E} / \mathrm{m}^{3}\right)$ due to the costs of feed. Net returns in L.E per $\mathrm{m}^{3}$. were $79.42 ; 81.51 ; 88.75$; 78.98; 55.87 and 53.0 for $\mathrm{T}_{1}$ (20\% Protein); $\mathrm{T}_{2}$ (25\% Protein); $\mathrm{T}_{3}(30 \%$ Protein); $\mathrm{T}_{4}$ (35\% Protein); $\mathrm{T}_{5}$ (40\% Protein) and $\mathrm{T}_{6}$ (45\% Protein); groups, respectively. Percentages of net return to total costs for treatments cited above were $99.4 \% ; 102.4 \% ; 110.3 \% ; 94.1 \% ; 59 \%$ and $68.6 \%$, respectively indicating that the highest net returns were obtained with the group $T_{3}$ (30\% Protein). From the economical point of view, results suggest that the protein level of $30 \%$ for Nile tilapia 
(weighing 20g) is recommended to achieve the highest percentages of net returns to total costs.

In conclusion, the optimum dietary protein level for Nise tilapia (weighing 20g) was $30 \%$ and the feeding rate was $3 \%$ of body weight.

\section{REFERENCES}

A.O.A.C. (1980). Association of official Analytical Chemists. In: Horowitz (Editors), official Methods of Analysis, $11^{\text {th }}$ edition. Washington, DC.

Atack, T. H. ; Jauncey, K. and Matty, A. J. (1979). The utilization of some single-celled protein by fingerlings of mirror carp (Cyprinus carpic L.). Aquacuil., 18: 337-348.

Balarin, J. D. and Hailer, R. D (1982). The intensive culture of tilapia tanks, raceways and cages. In; J.F. Muir and R.J. Roberts (Editors), Recent Advarices in Aquaculture. Croom Helm Ltd. London, pp. 265-355.

Brown, M. E. (1957). The physiology of fishes. Vol 1. Academic press.

Cowey, C. B. ; Mackie, A. M. and Bell. J. G. (1985). Nutrition and feeding in fish. Acad. Press p.1.

Dabrowski, k. and Wojno, T. (1977). Studies on the utilization by rainbow trout (Salmo gairdneri) of feed mixtures containing soybean meal and an addition of amino acids. Aquacult., 10 : $297-310$.

Dabrowski, K. (1977). Protein requirements of grass carp fry (Ctenopharyngodon idella Val.). Aquacult., 12:663 - 73.

De Silva, S. S. and Perera, M. K. (1985). Effects of dietary protein levels on growth, food conversion and protein use in young Tilapia nilotica at four salinities. Trans. Am. Fish. Soc., 114: $589-589$. 
Jauncey, K. and Rose, B. (1982). A guide to tilapia reets but reeding. Institute of Aquacult., Univ. of Stenting, Bcotime?.

NRC, (1983). Nutrient requirements of Warnisu Fishes Shelifishes. National Rresearch Council, National Academy Press. Washington DC., USA. 102pp.

Ogino, C. and Saito, k., (1970). Protein nutrition in Fish. 1. The utilization of dietary protein by carp. Bull. Jpn. Soc. Sci. Fish., 36:250-254.

Ogino, C. ; Chiou, J.Y. and Takeuchi, T. (1976). Protein nutrition in Fish. V1. Effects of dietary energy sucrose on the utilization of protein by rainbow trout and carp. Bull. Jpn. Soc. Sci. Fish., 42: 213-218.

Santiago, C. B. ; Banes-Aldaba, M. and London, M. A. (1982). Dietary crude protein requirement of Tilapia nilotica Fry. Kalikasan Philipp. J. Biol., $11: 255-265$.

Siḍdiqui, A. Q. ; Howloder, M. S. and Adam, A. A. (1988). Effects of dietary protein levels on growth, feed conversion and protein utilization in fry and young Nile tilapia (Oreochromis niloticus). Aquacult., $70: 63-73$.

Snedecor, G. W. and Cochran, W. G. (1980). Statistical Methods. Pp. 143. low State Univ. press, Ames., lowa.

Viola, S. and Arieli, Y. (1983). Nutrition studies with tilapia (Sarotherodon). Replacement of fish meal by soybean meal in feeds for intensive tilapia culture. Bamidgeh, 35 (1) 9-17.

Wang, K. W. ; Takeuchi, T. and Watanbe, T. (1985). Effect of dietary protein levels on growth of Tilapia nilotica. Bull. Jap., Soc. Sci. fish., 51: 331-140. (English Summary).

Winberg; G. G. (1960). Rate of Metabolism and food Requirement of fish. J. fish. Res. Board. Can. 194, 202. 
EFFECT OF PROTEIN LEVELS ON GROWTH AND ECONOMTCAL EVALUATION OF NEE TLAPIA

Table (1): composition and proximate analysis of experimental diets.

\begin{tabular}{|l|c|c|c|c|c|c|}
\hline \multicolumn{1}{|c|}{ Ingredient } & \multicolumn{6}{|c|}{ Diê No. } \\
\cline { 2 - 7 } & $\mathbf{1}$ & $\mathbf{2}$ & $\mathbf{3}$ & $\mathbf{4}$ & $\mathbf{5}$ & $\mathbf{6}$ \\
\hline Fish meal (58\%) & 34.50 & 43.50 & 52.00 & 60.40 & 69.00 & 71.60 \\
Starch & 49.50 & 41.50 & 32.50 & 26.60 & 18.00 & 10.40 \\
Fish oil & 5.00 & 4.00 & 4.50 & 2.00 & 2.00 & 1.00 \\
Mineral Mix. & 3.00 & 3.00 & 3.00 & 3.00 & 3.00 & 3.00 \\
Vitamin mix. & 2.00 & 2.00 & 2.00 & 2.00 & 2.00 & 2.00 \\
Cellulose & 5.00 & 5.00 & 5.00 & 5.00 & 5.00 & 5.00 \\
CNC (1) & 1.00 & 1.00 & 1.00 & 1.00 & 1.00 & 1.00 \\
Proximate analysis & & & & & & \\
Moisture \% & 8.30 & 8.70 & 9.50 & 8.60 & 10.40 & 9.50 \\
Crude protein \% & 20.10 & 25.20 & 30.10 & 35.00 & 40.10 & 45.00 \\
Ether extract \% & 9.50 & 9.70 & 11.20 & 10.00 & 11.20 & 11.30 \\
Crude fiber \% & 5.00 & 5.20 & 5.70 & 5.90 & 3.90 & 5.90 \\
Ash & 10.10 & 11.10 & 13.50 & 14.60 & 16.30 & 19.30 \\
NFE (2) & 47.00 & 40.10 & 30.00 & 25.90 & 16.10 & 9.00 \\
GE (3) Kcal / 100 g. & 396.04 & 398.45 & 398.90 & 398.44 & 398.40 & 397.9 \\
& & & & & & 3 \\
ME (4) Kcal / 100 g. & 349.80 & 348.20 & 344.65 & 340.92 & 336.83 & 332.7 \\
\end{tabular}

1- Carboxymethyl cellulose.

2- Nitrogen free extract.

3- Based on $5.65 \mathrm{kcal} / \mathrm{g}$ protein, $9.45 \mathrm{kcal} / \mathrm{g}$ fats \& $4.1 \mathrm{Kcal} / \mathrm{g}$ carbohydrate (Pantha, 1982).

4- Metabolizable energy based on $4.5 \mathrm{kcal} / \mathrm{g}$. protein, $8.5 \mathrm{Kcal} / \mathrm{g}$ fat and $3.8 \mathrm{kcal} / \mathrm{g}$ digestible carbohydrate (Jauncey and Ross, 1982). 
Abd El-Hamid Eid et al.

Table (2): The performance of Nile tilapia as affected y dielary protein level.

\begin{tabular}{|c|c|c|c|c|c|c|}
\hline \multirow[b]{2}{*}{ CP 1} & \multicolumn{6}{|c|}{ Diet Nis. } \\
\hline & $\begin{array}{c}1 \\
20 \%\end{array}$ & $\begin{array}{c}2 \\
25 \%\end{array}$ & $\begin{array}{c}3 \\
30 \%\end{array}$ & $\begin{array}{c}4 \\
35 \%\end{array}$ & $40 \%$ & $\begin{array}{c}6 \\
45 \%\end{array}$ \\
\hline Initial weight $(\mathrm{g})$ & 20.10 & 20.10 & 20.10 & 20.10 & 20.10 & 20.10 \\
\hline Fin & 53.10 & 3.70 & 56.40 & 54.30 & .50 .20 & $54.00^{\circ}$ \\
\hline weight gain (g) & $33.0 \mathrm{a}$ & $33.6 \mathrm{a}$ & $36.30 \mathrm{c}$ & $34.20 \mathrm{~b}$ & $34.10 \mathrm{~b}$ & $33.9 \mathrm{~b}$ \\
\hline Feed intake & $97.2 \mathrm{a}$ & $70.56 a$ & $65.34 d$ & $64.98 \mathrm{a}$ & $75.02 \mathrm{~b}$ & $88.14 c$ \\
\hline RGR 2 & $164.18 \mathrm{a}$ & $167.16 \mathrm{a}$ & $180.60 \mathrm{c}$ & $170.14 b$ & $169.65 \mathrm{~b}$ & $168.66 \mathrm{~b}$ \\
\hline SGR 3 & $1.01 \mathrm{a}$ & $1.67 \mathrm{a}$ & $1.71 \mathrm{c}$ & $1.66 \mathrm{~b}$ & $1.52 \mathrm{~b}$ & $1.65 b$ \\
\hline FCR 4 & $2.40 \mathrm{~b}$ & $2.10 \mathrm{a}$ & $1.80 \mathrm{a}$ & $1.90 \mathrm{a}$ & $2.20 \mathrm{ab}$ & $2.60 \mathrm{c}$ \\
\hline PER 5 & $2.08 \mathrm{e}$ & $1.90 \mathrm{~d}$ & $1.85 \mathrm{~d}$ & $1.50 \mathrm{c}$ & $1.13 b$ & $0.85 \mathrm{a}$ \\
\hline FE 6 & $0.42 \mathrm{~b}$ & $0.48 b$ & $0.55 \mathrm{c}$ & $0.53 \mathrm{c}$ & $0.45 b$ & $0.38 \mathrm{a}$ \\
\hline
\end{tabular}

1- Crude protein $(\%)$.

2 Relative Growth Rate $=\frac{\text { Finial }}{\text { Initial }} \times 100$

Final wt - Initial wt

(Winberg, 1960)

2- Specific Growth Rate ( $\%$ day $)=$

$$
\text { - } \log _{\mathrm{e}} \frac{\mathrm{W} 1-\log _{\mathrm{e}} W_{\mathrm{O}}}{\mathrm{T} 1-\mathrm{T}_{\mathrm{O}}} \times 100
$$

(Brown, 1957)

Where $\mathrm{W} 1$ and $\mathrm{Wo}=$ final and initial weights $(\mathrm{g})$ respectively.

$\mathrm{Tl}$ and $\mathrm{To}=$ final and initial time (days)

$\log _{\mathrm{e}}=$ Natural logarithm to base $\mathrm{e}$

4- Feed Conversion Ratio $=$ Feed intake $(\mathrm{g}) /$ wet weight gain

5- Protein Efficiency Ratio = wet weight gain / protein intake.

6- Feed Efficiency = wet weight gain / dry wt feed offered. 

AND ECONOMICAL EVALUATION OF NILE TULAPLA

Table (3): Gross body composition of experimental fish fed different dietary protein levels at the beginning and end of the experiment (values are expressed as \%, wet weight basis).

\begin{tabular}{|l|c|c|c|c|}
\hline \multicolumn{1}{|c|}{ Diet } & \multicolumn{4}{|c|}{ Body composition } \\
\cline { 2 - 5 } & Moisture & Protein & Fat & Ash \\
\hline Initial & 73.10 & 14.55 & 6.80 & 5.55 \\
$20 \%$ Crude protein & $72.60 \mathrm{a}$ & $14.10 \mathrm{a}$ & $7.70 \mathrm{c}$ & $5.60 \mathrm{a}$ \\
$25 \%$ Crude protein & $73.30 \mathrm{a}$ & $14.60 \mathrm{a}$ & $7.10 \mathrm{ab}$ & $5.00 \mathrm{a}$ \\
$30 \%$ Crude protein & $73.79 \mathrm{a}$ & $15.56 \mathrm{a}$ & $6.55 \mathrm{a}$ & $4.10 \mathrm{a}$ \\
$35 \%$ Crude protein & $73.00 \mathrm{a}$ & $15.78 \mathrm{a}$ & $6.50 \mathrm{a}$ & $4.72 \mathrm{a}$ \\
$40 \%$ Crude protein & $73.30 \mathrm{a}$ & $16.00 \mathrm{a}$ & $6.55 \mathrm{a}$ & $4.15 \mathrm{a}$ \\
$45 \%$ Crude protein & $72.40 \mathrm{a}$ & $16.30 \mathrm{a}$ & $6.80 \mathrm{a}$ & $4.50 \mathrm{a}$ \\
\hline
\end{tabular}

Figures in the same column having the same superscript are not significantly different $(P<0.50)$.

Table (4)_Economic efficiency (\%) for Nile tilapia (O. niloticus) as affected by dietary protein levels $\mathrm{Kg} . / \mathrm{M}^{3}$ (L.E.) for 180 days.

\begin{tabular}{|c|c|c|c|c|c|c|c|}
\hline \multicolumn{2}{|c|}{ Treatments } & \multirow{2}{*}{$\begin{array}{c}1 \\
20 \%\end{array}$} & \multirow{2}{*}{$\begin{array}{c}2 \\
25 \%\end{array}$} & \multirow{2}{*}{$\begin{array}{c}3 \\
30 \%\end{array}$} & \multirow{2}{*}{$\begin{array}{c}4 \\
35 \%\end{array}$} & \multirow{2}{*}{$\begin{array}{c}5 \\
40 \%\end{array}$} & \multirow{2}{*}{$\begin{array}{c}6 \\
45 \%\end{array}$} \\
\hline \multicolumn{2}{|c|}{ Costs and Returns } & & & & & & \\
\hline \multirow[t]{3}{*}{ Costs } & Fingerlings & 41.25 & 41.25 & 41.25 & 41.25 & 41.25 & 41.25 \\
\hline & Feed & 38.61 & 38.36 & 39.20 & 42.65 & 53.44 & 67.75 \\
\hline & Total & 79.86 & 79.61 & $\overline{80.45}$ & 83.9 & 94.69 & 109.0 \\
\hline \multirow[t]{4}{*}{ Returns } & Production & 19.91 & 20.14 & 21.15 & 20.36 & 18.82 & 20.25 \\
\hline & Fish sales & 159.28 & 161.12 & 169.2 & 162.88 & $\begin{array}{c}150.5 \\
6\end{array}$ & 162.0 \\
\hline & Net returns & 79.42 & 81.51 & 88.75 & 78.98 & 55.87 & 53.0 \\
\hline & $\begin{array}{l}\% \text { smallest } \\
\text { value of } \\
\text { total costs }\end{array}$ & $150 \%$ & $154 \%$ & $167 \%$ & $149 \%$ & $\begin{array}{c}105 \\
\%\end{array}$ & $100 \%$ \\
\hline $\begin{array}{l}\text { Economi } \\
\mathrm{c} \\
\text { Efficienc } \\
\mathrm{y}\end{array}$ & $\begin{array}{l}\% \text { Net } \\
\text { return to } \\
\text { total costs }\end{array}$ & $99.4 \%$ & $\begin{array}{c}102.4 \\
\%\end{array}$ & $\begin{array}{c}110.3 \\
\%\end{array}$ & $94.1 \%$ & $59 \%$ & $48.6 \%$ \\
\hline
\end{tabular}

The economical evaluation of results was carried out according to market prices in 2003 in L. E. 